\title{
Nutritional and health benefits of legumes and their distinctive genomic properties
}

\author{
Özgür ÇAKIR ${ }^{1 *}$, Cüneyt UÇARLI ${ }^{1}$, Çağatay TARHAN ${ }^{1}$, Murat PEKMEZ1 ${ }^{1}$, Neslihan TURGUT-KARA ${ }^{1}$
}

\begin{abstract}
Legumes are indispensable for human diet in respect to their valuable and nutritive bioactive molecules. Legumes and derivative foodstuffs are rich in fiber, proteins, vitamins and some valuable phytochemicals, which exhibit important biological activities. Due to their remarkable molecular content, they are receiving great attention by researchers. Recent developments in genomics and bioinformatics led to cumulative data about legume genomes. These data could provide important information to accelerate breeding and to develop new traits for biofortification. The main focus of this review is to present their distinctive genomic properties by summarizing significant studies conducted with relatively newly developed techniques revealing the beneficial effects of bioactive molecules from legumes on human health.
\end{abstract}

Keywords: Leguminosae; nutritional properties; health; bioactive compounds; legume genomes.

Practical Application: Nutritional and health benefits of legumes and their distinctive genomic properties.

\section{Introduction}

Legumes are the third largest family of angiosperms belong to Fabaceae/Leguminosae (Gepts et al., 2005). Pulses are the important components of a healthy diet and take an important place in the traditional diets throughout the World (Malaguti et al., 2014). This family includes peas, lentils, beans, peanuts and other podded plants that are consumed as food (Messina, 1999). They provide a range of essential nutrients including protein, low glycemic index carbohydrates, dietary fibre, minerals and vitamins. Legumes are uniquely rich in both protein and dietary fibre (Table 1). In addition, legumes are richer in protein than other cultivated plants because of the nitrogen-fixing bacteria live in the nodules of legume roots (Kouris-Blazos \& Belski, 2016). Protein derived bioactive peptides of legume plants have many important roles as health-enhancing compounds (especially interact with amino acids of enzymes related with diseases). Presence of these bioactive peptides in legumes may contribute to the food quality (López-Barrios et al., 2014; Ortiz-Martinez et al., 2014). Also, the observed effects on diseases including cardiovascular diseases, diabetes, cancer and obesity, may derive from the synergistic combination of bioactive compounds of legume seeds (Arnoldi et al., 2015). There are many reports regarding that these peptides have different activities and described as antimicrobial properties, blood pressure-lowering effects, cholesterol-lowering ability, antithrombotic, antioxidant activities, enhancement of mineral absorption/bioavailability, cyto- or immunomodulatory effects, and opioid-like activities (Mejia \& Dia, 2010; Li et al., 2013; Möller et al., 2008; Zambrowicz et al., 2013). Among the legumes, soybean (Glycine max L.) is widely used in human and animal diet because of its nutritional value. Soybean seed has high quality proteins in the manner of nutrition when compared to other legume seeds (Natarajan et al., 2013). After the developments in genetic engineering technologies, modified soybean varieties has been developed to address insusceptible conditions (Zhang et al., 2016). Today, $83 \%$ of all soybeans planted is genetically modified (GM) soybean in the world (about 92.1 million hectares) (James, 2009).

Even though noteworthy progress has been made in decreasing hunger globally, 795 million people are still underweight, with over 2 billion people having micronutrient deficiencies, and approximated 161 million children under 5 years of age are undersized and, 99 million are undernourished (Amoroso, 2016). Regarding the global nutrient deficiencies, legumes play major role as a part of the farming structure of the developing world. To solve the global food shortage problem, improving the quality of legume grains using recent technologies can be adapted as a strategy. By means of research projects focusing on biofortification of the legume grains, which use genomics technologies, could rapidly meet the expectations. These technologies would help to explore whole genome in a short time, then enlighten the scientists to determine target gene regulating DNA regions related to biofortification (Gupta, 2014; White \& Broadley, 2009). Rapidly growing methods in the genomic area have shown to be accurate analysis tools for plants (Bohra et al., 2015; Varshney et al., 2015). Decreasing costs along with rapid progress in next-generation sequencing (NGS) and bioinformatics analysis resources have facilitated discovery of whole genome sequences of legume plants. Consequently, new NGS assays like genotyping-by-sequencing (GBS) and whole genome re-sequencing (WGRS) could assist researchers in the evaluation of genetic diversity of model plants and also for the non-model grain legumes (Bohra et al., 2014; Poland \& Rife, 2012).

The general view is that today it would be insignificant to discuss the legumes without taking into consideration of their genomic properties. The main aim of this review is to display the features of legumes in genomic perspective while discussing the present status of them on human nutrition and health. 
Table 1. Nutrient values of various legumes per $100 \mathrm{~g}^{\star}$.

\begin{tabular}{|c|c|c|c|c|c|c|c|c|}
\hline & Unit & Soybeans & Peas & lentils & Lupins & Chickpea & White bean & Black bean \\
\hline Energy & kcal & 172 & 118 & 116 & 119 & 164 & 139 & 132 \\
\hline Protein & $\mathrm{g}$ & 18.21 & 8.34 & 9.02 & 15.57 & 8.86 & 9.73 & 8.86 \\
\hline Fat & $\mathrm{g}$ & 8.97 & 0.39 & 0.38 & 2.92 & 2.59 & 0.35 & 0.54 \\
\hline Carbohydrate & $\mathrm{g}$ & 8.36 & 21.10 & 20.13 & 9.88 & 27.42 & 25.09 & 23.71 \\
\hline Dietary Fiber & $\mathrm{g}$ & 6 & 8.3 & 7.9 & 2.8 & 7.6 & 6.3 & 8.7 \\
\hline \multicolumn{9}{|l|}{ Minerals } \\
\hline Calcium, Ca & $\mathrm{mg}$ & 102 & 14 & 19 & 51 & 49 & 90 & 27 \\
\hline Iron, $\mathrm{Fe}$ & $\mathrm{mg}$ & 5.14 & 1.29 & 3.33 & 1.20 & 2.89 & 3.70 & 2.10 \\
\hline Magnesium, Mg & $\mathrm{mg}$ & 86 & 36 & 36 & 54 & 48 & 63 & 70 \\
\hline Phosphorus, $\mathrm{P}$ & $\mathrm{mg}$ & 245 & 99 & 180 & 128 & 168 & 113 & 140 \\
\hline Potassium, K & $\mathrm{mg}$ & 515 & 362 & 369 & 245 & 291 & 561 & 355 \\
\hline Sodium, $\mathrm{Na}$ & $\mathrm{mg}$ & 1 & 2 & 2 & 4 & 7 & 6 & 1 \\
\hline Zinc, Zn & $\mathrm{mg}$ & 1.15 & 1.00 & 1.27 & 1.38 & 1.53 & 1.38 & 1.12 \\
\hline \multicolumn{9}{|l|}{ Vitamins } \\
\hline Vitamin C & $\mathrm{mg}$ & 1.7 & 0.4 & 1.5 & 1.1 & 1.3 & 0.0 & 0.0 \\
\hline Thiamin & $\mathrm{mg}$ & 0.155 & 0.190 & 0.169 & 0.134 & 0.116 & 0.118 & 0.244 \\
\hline Riboflavin & $\mathrm{mg}$ & 0.285 & 0.056 & 0.073 & 0.053 & 0.063 & 0.046 & 0.059 \\
\hline Niacin & $\mathrm{mg}$ & 0.399 & 0.890 & 1.060 & 0.495 & 0.526 & 0.140 & 0.505 \\
\hline Vitamin B-6 & $\mathrm{mg}$ & 0.234 & 0.048 & 0.178 & 0.009 & 0.139 & 0.093 & 0.069 \\
\hline Folate, DFE & $\mu \mathrm{g}$ & 54 & 65 & 181 & 59 & 172 & 81 & 149 \\
\hline Vitamin B-12 & $\mu \mathrm{g}$ & 0.00 & 0.00 & 0.00 & 0.00 & 0.00 & 0.00 & 0.00 \\
\hline Vitamin A, IU & IU & 9 & 7 & 8 & 7 & 27 & 0 & 6 \\
\hline Vitamin D & IU & 0 & 0 & 0 & 0 & 0 & 0 & 0 \\
\hline Vitamin E & $\mathrm{mg}$ & & 0.03 & 0.11 & & & 0.94 & 0.87 \\
\hline Vitamin K & $\mu \mathrm{g}$ & & 5.0 & 1.7 & & 4 & 3.5 & 3.3 \\
\hline \multicolumn{9}{|l|}{ Lipids } \\
\hline Fatty acids, total saturated & g & 1.297 & 0.054 & 0.053 & 0.346 & 0.269 & 0.091 & 0.139 \\
\hline Fatty acids, total monounsaturated & $\mathrm{g}$ & 1.981 & 0.081 & 0.064 & 1.180 & 0.583 & 0.031 & 0.047 \\
\hline Fatty acids, total polyunsaturated & g & 5.064 & 0.165 & 0.175 & 0.730 & 1.156 & 0.152 & 0.231 \\
\hline Fatty acids, total trans & $\mathrm{g}$ & 0.00 & 0.000 & 0.000 & 0.000 & 0.000 & 0.000 & 0.000 \\
\hline
\end{tabular}

${ }^{*}$ Values from USDA standart reference release 28 and based on edible portions of mature seeds, cooked, boiled without salt. National Nutrient Database for Standard Reference Release 28.

\section{Importance of legumes regarding bioactive compounds and human health}

There are numerous groups which can be classified as bioactive protein and peptide derivatives, phytosterols, isoflavones, saponins, alkaloids and bioactive carbohydrates. Mostly studied, lunasin, Bowman-Birk protease inhibitor (BBI) and soy isoflavones are bioactive components of the legumes. Lunasin is found in soybean and also detected in wheat, barley, rice, rye, triticale and amaranth (Jeong et al., 2007; Jeong et al., 2009; Jeong et al., 2010; Park et al., 2005). It is encoded within $2 \mathrm{~S}$ albumin (GM2S-1) gene and composed of 43 amino acid residues with molecular weight of $5.5 \mathrm{kDa}$. Health-promoting effects of lunasin can be sorted as anti-inflammatory, cholesterol lowering, anticancerous and antioxidant activity (Hsieh et al., 2018). Its bioactive properties come from the capability of arresting cell division in cancer cells, inhibiting core histone acetylation in mammalian cells and protecting DNA from oxidative damage. Generally, it is estimated that the mechanism of lunasin to act as anticancer agent is to disturb histone acetylation and deacetylation. Hereby, inactivation of some tumor suppressor proteins as Rb, p53 and pp32 is reported (Lumen, 2005; Galvez et al., 2001;
Hernández-Ledesma et al., 2011; Jeong et al., 2007; Jeong et al., 2002). Bowman-Birk inhibitor (BBI) is one of the major classes of legume produced protease inhibitors, and composed of 70-80 amino acids with a molecular weight of $8 \mathrm{kDa}$. It is found in soy as well in lentil and pea. BBI has many functions such as regulation of protease activity during seed germination and protection of plants from insects and microorganisms, also there are studies reporting the preventive effect of BBI against prostate, breast and colon cancers (Chan et al., 2013; Mejia \& Dia, 2010; Hernández-Ledesma et al., 2009; Park et al., 2005). Proteasome activity is known to be increased in many cancer cells compared to non-transformed cells (Souza et al., 2014) and proteasome inhibition may result homeostasis disruption of the cancer cells. Based on this information, proteasome inhibitors might be used for cancer therapy, also BBI may be an important compound that has a potential to be used in cancer prevention. The proposed mechanism is the induction of tumor suppressor gene connexin $43(\mathrm{Cx} 43)$ and cell cycle arrest in G1/S phase (Chen et al., 2005; Saito et al., 2007).

Another group of bioactive proteins is lectins, which have the ability to agglutinate cells due to their binding to specific 
carbohydrate residues on the cell surface. Liener (1991), first reported that soybean aglutinin could inhibit tumor growth in a rat model demonstrating of anticancer properties of soybean lectins. Boland et al. (1992) demostrated that soybean lectins improve the life expectancy in a lymphoma mouse model.

Besides these bioactive peptides, other phytochemicals (isoflavones, saponins, alkaloids) in legumes have been reported to have potential benefit in human health. It is reported that isoflavones are largely isolated from the Fabaceae family (Leguminosaea) (Rochfort \& Panozzo, 2007). Isoflavones have been shown to have several biological activities including reduction in osteoporosis, prevention of cancer and cardivovascular disease (Table 2) (Cooke, 2006; Manach et al., 2005; Martínez et al., 2006; Messina et al., 2006; Trock et al., 2006). Isoflavones can also be used for the treatment of symptoms of menopause (Li et al., 2015). Saponins are another class of phytochemicals, and they are included as soya saponins classified into group A, B, and E saponins on the chemical basis of the chemical structure of their aglycone. They have been also reported to be found in lupins (Woldemichael et al., 2003; Woldemichael \& Wink, 2002), lentils (Rochfort \& Panozzo, 2007; Ruiz et al., 1996), chickpeas, various beans, as well as soy (Shi et al., 2004). It has been suggested that legumous saponins may have anticancer activity, and be beneficial for hyperlipidemia (Chang et al., 2006; Ellington et al., 2006; Shi et al., 2004; Zou et al., 2006).

Alkaloids from edible legumes have been reported from lupins. One of the alkaloid trigonelline has been reported from peas (Hammouda \& Ahmed, 1962), also low levels of alkaloids were detected from chickpeas and lentils. One of the report discusses the enhancement of insulin secretion by lupin quinolizidine alkaloids (López et al., 2004).

Legumes can reduce cholesterol, blood pressure, inflammation, weight and blood pressure lead to cardiovascular disease (CVD) due to their valuable content (Abeysekara et al., 2012; Flight \& Clifton, 2006; Hermsdorff et al., 2011; Nilsson et al., 2013). Low serum cholesterol and and low-density lipoprotein cholesterol (LDL-C) have an inverse correlation with coronary heart disease (CHD) mortality because of the high levels of saponins and phytosterols (Kouris-Blazos \& Belski, 2016). There are some studies reporting the reduce of CHD by consumption of legumes because of their high saponin and phytosterol contents (Afshin et al., 2014; Bazzano et al., 2001; Nagura et al., 2009). The consumption of dry legumes with a low saturated-fat diet may help improve the lipid homeostasis and as a result reduce the risk of CVD (Duranti, 2006).

The prevalence of diabetes mellitus (DM) is rapidly increasing worldwide as a result of population growth, ageing, urbanization and lifestyle changes leading obesity and physical inactivity (Chen et al., 2011; Zimmet et al., 2001). Legumes have been demonstrated to improve the glycemic control in type $2 \mathrm{DM}$ patients because of higher amount of resistant starch and amylose content (Thorne et al., 1983). The increased consumption of resistant starch is related to improved glucose tolerance and insulin sensitivity (Jukanti et al., 2012). Short-term studies have shown that legume consumption lowers blood glucose and insulin responses and increases insulin sensitivity (Nestel et al., 2004). The protective effect of legumes on type $2 \mathrm{DM}$ may be as a result of high fiber content, low glycemic index and a range of potentially bioactive nutrients including isoflavones and lignans (Kalogeropoulos et al., 2010).

The glycated hemoglobin A1c (HbA1c) is considered as the gold-statement to determine blood sugar control over time and acceptable HbA1c levels are below 6.5\% according to the American Diabetes Association (2011) and The World Health Organization (2011). When legumes were consumed in low-glycaemic index (GI) diets, HbA1c level also was lowered in both diabetic and non-diabetic individuals. Legumes in high-fibre diets also significantly reduced FBG (Fasting Blood Glucose) and $\mathrm{HbA1c}$ level. Thus, the consumption of legumes, alone or in low-GI or high-fibre diets, improves markers of longer term glycaemic control in humans (Sievenpiper et al., 2009). The recent randomised controlled studies have also demonstrated that legumes, as part of a low GI diet, are associated with long-term improvements in $\mathrm{HbA} 1 \mathrm{c}$ and lowered risk of developing type 2 DM (Dong et al., 2011; Jenkins et al., 2012). Legumes also have been shown to improve insulin sensitivity, whilst they are as part of high carbohydrate and GI diets (Simpson et al., 1981).

Overweight and obesity have been related chronic diseases and contributed to morbidity and mortality, including cardiovascular and metabolic disorders as well as certain types of cancers such as colorectal cancer, lung cancer, esophageal adenocarcinoma and breast cancer (Abete et al., 2010; Calle et al., 2003; Jemal et al., 2011). Legumes are rich in low glycemic index carbohydrates, resistant starch, oligosaccharides and fibre, and also demonstrated to decrease hunger and acute food intake therefore consumption of legumes, can aid in the management of obesity and obesity-related mortality (Muzquiz et al., 2012; Rebello et al., 2014; Wanders et al., 2011). Bean extracts containing digestive enzyme $\alpha$-amylase inhibitors were demonstrated to reduce starch digestion leading to significantly reduction of body weight, body mass index (BMI) and fat mass (Celleno et al., 2007).

Legumes, particulary, beans contain bioactive components like phenolic compounds (flavonoids, tannins, and anthocyanin), protease inhibitors, phytic acid, and saponins. These components have helped in the inhibition of colon cancer (Table 2) (Harland \& Morris, 1995; Kennedy, 1994; Kinjo et al., 1998). Colon rectal cancer (CRC), being highly metastatic and resistant to anticancer treatment strategies, is the third most common cause of cancer death in the developed and developing countries (Markle et al., 2010; Siegel et al., 2014). The case-control studies have shown that legume consumption is related to a decrease in the risk of CRC (Aune et al., 2009). Furthermore, preclinical research has also revealed that feeding of laboratory animals with $100 \mathrm{~g}$ of diet including $75 \mathrm{~g}$ black or navy beans can reduce both the incidence and the number of colon tumors by $50 \%$ (Bennink, 2002). There are a number of phytochemicals in legumes shown anticarcinogenic activity; these include phytoestrogens, a variety of phenolic acids, phytosterols, protease inhibitors, saponins, phytates, fiber, proteins, and fatty acids (Mathers, 2002; Messina, 1999).

Protein extracts from some legume seeds, particularly albumins and globulins, can reduce cell migration in colon carcinoma cells. Effectiveness of seed proteins in inhibition of gelatinases (MMP-9) activities which is known to be linked to 
Table 2. Effects of legumes on cardiovascular diseases, diabetes and cancers.

\begin{tabular}{|c|c|c|c|c|}
\hline Legume Source & Involved metabolism & Type of study & Beneficial effect & Reference \\
\hline $\begin{array}{l}\text { Dry beans, peas and } \\
\text { peanuts }\end{array}$ & Cardiovascular & $\begin{array}{l}\text { Epidemiologic Follow-up } \\
\text { Study }\end{array}$ & $\begin{array}{l}22 \% \text { reduction in coronary } \\
\text { heart disease }(\mathrm{CHD}) \\
\text { and } 11 \% \text { reduction in } \\
\text { cardiovascular disease } \\
\text { (CVD) }\end{array}$ & Bazzano et al. (2001) \\
\hline Legumes & Cardiovascular & Meta-analysis & $\begin{array}{l}\text { Decreased risk of } 10 \% \text { in } \\
\text { both CVD and CHD }\end{array}$ & Marventano et al. (2017) \\
\hline Baked beans & Hypercholesterolemia & $\begin{array}{l}\text { unblinded, } 2 \times 2 \\
\text { randomized crossover with } \\
\text { baked bean treatment and a } \\
\text { control treatment }\end{array}$ & $\begin{array}{l}5.6 \% \text { reduction in total } \\
\text { cholesterol and } 5.4 \% \text { in } \\
\text { low-density lipoprotein } \\
\text { cholesterol }\end{array}$ & Winham \& Hutchins (2007) \\
\hline $\begin{array}{l}\text { Cooked beans, chickpeas } \\
\text { or lentils }\end{array}$ & Cardiovascular and diabetic & randomized controlled trial & $\begin{array}{l}\text { Reduced hemoglobinA1c } \\
(\mathrm{HbA} 1 \mathrm{c}) \text { level and } \\
\text { reduction in coronary heart } \\
\text { disease }(\mathrm{CHD}) \text { risk }\end{array}$ & Jenkins et al. (2012) \\
\hline $\begin{array}{l}\text { Five cups/week yellow peas, } \\
\text { chickpeas, navy beans and } \\
\text { lentils) }\end{array}$ & Metabolic syndrome & $\begin{array}{l}\text { Randomized Controlled } \\
\text { Trial }\end{array}$ & $\begin{array}{l}\text { Reduced risk factors of the } \\
\text { Metabolic syndrome }\end{array}$ & Mollard et al. (2012) \\
\hline Beans with low-GI diet & Glycaemia and obesity & $\begin{array}{l}\text { randomized, crossover } \\
\text { study }\end{array}$ & $\begin{array}{l}\text { Improvement in metabolic } \\
\text { control in type } 2 \text { obese } \\
\text { diabetic patients and weight } \\
\text { loss }\end{array}$ & Jimenez-Cruz et al. (2003) \\
\hline Azuki bean juice & Hypertriglyceridemia & $\begin{array}{l}\text { Randomized double-blind } \\
\text { parallel-group trial }\end{array}$ & $\begin{array}{l}\text { Reduction in triglyceride } \\
\text { by suppression of lipase } \\
\text { inhibitory activity }\end{array}$ & Maruyama et al. (2008) \\
\hline Legume seed extracts & Colon cancer & Test-tube Lab Research & $\begin{array}{l}\text { Inhibition of MMP-9 } \\
\text { activity and cell migration } \\
\text { in colon carcinoma cells. }\end{array}$ & Lima et al. (2016) \\
\hline $\begin{array}{l}\text { Raw or cooked- bean } \\
\text { extracts }\end{array}$ & Colon cancer & Animal Research Studies & $\begin{array}{l}\text { Inhibition of aberrant foci } \\
\text { crypt development in rat } \\
\text { colon }\end{array}$ & Feregrino-Perez et al. (2008) \\
\hline $\begin{array}{l}\text { Lunasin peptides isolated } \\
\text { from soybean }\end{array}$ & Colon cancer & Test-tube Lab Research & $\begin{array}{l}\text { Lunasin caused a G2/M cell } \\
\text { cycle arrest on HT- } 29 \text { colon } \\
\text { cancer cells }\end{array}$ & Caccialupi et al. (2010) \\
\hline $\begin{array}{l}\text { Protein isolates of } \\
\text { germinated soybean }\end{array}$ & Cervical cancer & Animal Research Studies & $\begin{array}{l}\text { Decreased in the expression } \\
\text { of PTTG1 and TOP } 2 \mathrm{~A} \\
\text { ( } 2 \text { genes considered as } \\
\text { therapeutic targets) causing } \\
\text { apoptosis of cancer cells. }\end{array}$ & Robles-Ramírez et al. (2012) \\
\hline Soybean soyasaponin I & Skin cancer & Animal Research Studies & $\begin{array}{l}\text { Decreased in the expression } \\
\text { of } a-2,3 \text {-linked sialic acid } \\
\text { on the cell surface, which } \\
\text { in turn suppresses the } \\
\text { metastatic potential of } \\
\text { melanoma cells }\end{array}$ & Chang et al. (2006) \\
\hline $\begin{array}{l}\text { Lunasin peptides isolated } \\
\text { from soybean }\end{array}$ & Skin cancer & Test-tube Lab Research & Chemopreventive agent & Galvez et al. (2001) \\
\hline $\begin{array}{l}\text { Brown Kidney Bean } \\
\text { Bowman-Birk Trypsin } \\
\text { Inhibitor }\end{array}$ & Breast cancer & Test-tube Lab Research & $\begin{array}{l}\text { Inhibition of the } \\
\text { proliferation of human } \\
\text { breast cancer cells }\end{array}$ & Chan et al. (2013) \\
\hline
\end{tabular}


progression of CRC (Herszényi et al., 2012), is varied to legumes species. For example, mediterranean-type legume seeds contain most efficient MMP-9 inhibitors among the analyzed legumes, while pea seeds were less effective on HT29 cell proliferation and cell migration tests (Lima et al., 2016).

\section{Prominent genomic features of legumes}

Because of their nutritional, agricultural and ecological value, the legume biology has been of particular interest. The special features of the legumes such as nutritional value, Rhizobia-Legume symbiosis, and genetic characteristics that confer these phenotypic traits have long been investigated. The habitats of majority of the legumes are unfavorable environments including salinity, cold, drought, and variety of biotic stress (Dita et al., 2006). Therefore, it is important to investigate the stress response mechanisms in legumes not only to obtain more resistant varieties but also to understand their uniqueness among the other plant groups. These investigations have been carried out at the transcriptome, proteome and metabolome level. For example, proteomic analysis gives detailed information regarding the protein content associated with variety of stress responses (Kosová et al., 2011). It has been reported that symbiotic relationship between Medicago truncatula and Sinorhizobium meliloti strain 2011 affects drought responsive protein levels (Larrainzar et al., 2007). Besides, since the metabolites are direct indicators of regulatory mechanisms, it is important to detect their abundance and dynamic composition when legume specific responses to environmental perturbations are concerned (Obata \& Fernie, 2012). Scherling et al. (2010) demonstrated the differential metabolic profiling between legume and non-legume plants which grown in different conditions and found that changing environment had profound impact both on primary and secondary metabolism.

Nutritional breeding of legumes for high protein and mineral content stays critical to people. In order to allocate the biosynthetic pathways that highlight nutrient synthesis, nutrient accumulation and their transportation to the relevant plant parts, researchers need to lay emphasis on comprehending the complex mineral network. An enormous genomic pool promoting high-throughput recovery of DNA markers for instance SSRs (Single Sequence Repeats), single nucleotide polymorphisms (SNPs) and insertion-deletions (InDels) was exhibited by genome assemblies (Bohra \& Singh, 2015; Varshney et al., 2013). After analysing 90 genomes, diverse additional chickpea genome polymorphisms including both SNPs and InDels were revealed in addition to determining SSRs and SNPs based on genome scanning and RNA-seq analysis. By sequencing, genomic selection and genome-wide association studies, these resources will facilitate genomic-based breeding approaches like genotyping (Varshney et al., 2013). In genomics-based biofortification researches, the determination of the location of the important genes/quantitative trait loci (QTL) is an indispensable requirement. There is strong correlation with QTL determination and robust DNA marker determination. The correct molecular markers for edible plant parts could noticeably hasten the biofortification progress (Bohra et al., 2014). In order to identify the genomic location of gene(s)/QTLs which have quantitative effects on the phenotype, two QTL mapping methods like family-based linkage mapping and association analysis (so called LD mapping) are executed (Bohra, 2013; Mackay \& Powell, 2007; Mitchell-Olds, 2010; Würschum, 2012). For the detection of QTLs responsible for increased mineral concentrations in seeds, QTL analysis was conducted in two model legumes: Medicago truncatula and Lotus japonicus. As a result, 46 important QTLs altering mineral concentrations were determined in Medicago truncatula, and more than 100 QTLs were gained from Lotus japonicus (Klein \& Grusak, 2009; Sankaran et al., 2009). Forty QTLs of Medicago which affects nearly 18 different traits related to seed mineral concentrations, total nitrogen: total sulfur $(\mathrm{N}: \mathrm{S})$ ratio in seed, cysteine and methionine concentrations, were found out important (Ramamurthy et al., 2014). Furthermore, Scanning genomes of 94 different accessions with 1129 single nucleotide polymorphism (SNP) markers, a genome-wide association analysis was conducted recently in chickpea. As a result, SNPs were detected contributing towards $\mathrm{Fe}$ and $\mathrm{Zn}$ accumulation (Diapari et al., 2014).

Crops that typically have lower genetic diversity, can be introgressed by the pan-genome. Association between agronomic phenotypes, which inferred from homology and comparison with mapped QTLs, and genes with structural variation and large-effect variation can be used in order to develop molecular markers. These kind of data should empower the crop breeding community for more effective usage of molecular approaches. For instance, genomic selection in order to reduce the yield drag often accompanied with introgression from wild species (Bohra \& Singh, 2015). Because it determines the protein composition in particular organs and tissues at a given time, protein reference maps contribute greatly to understand the legume specificity (Watson et al., 2003). Lei et al. (2005) analysed the comprehensive proteome of M.truncatula and identified 1367 proteins and obtained 907 unique protein accession numbers. They also revealed that these proteins function in tricarboxylic acid cycle, glycolytic pathway and ubiquitin pathway and identified many enzymes involved in flavonoid/isoflavonoid, chalcone, and lignin biosynthesis using two-dimensional electrophoresis and nanoscale HPLC-MS/MS. Since symbiosis with rhizobia is a characteristic attribute, defining nodule proteome is especially important for the legumes. For this reason, reference maps have been constructed also for nodules in different species. Results obtained from these studies provide valuable insights into different features of protein dynamics in nodules. For example, it has been shown that post-translational modifications in proteins are more apparent in nodules in comparison with roots (Dam et al., 2014). In the same study, it was also shown that protein composition in nodules dramatically changed prior to and during nitrogen fixation. Dynamic changes in concentration and intertissue compartmentalization of proteins significantly affect the nutritional value of legume seeds. Legume seeds are highly rich in protein and other nutritious components as a distinguishing feature. The most important reason for this trait is the symbiotic relationship with nitrogen-fixing bacteria.

Legume genomes present distinct features as well. As a common characteristic, about 58 million years ago (Mya), a whole-genome duplication (WGD) took place in important legume families, and the best-knowns are M.truncatula, L. japonicus and G. max. It is thought that approximately 7.000 legumes share the same 
genome duplication event (Pfeil et al., 2005) and it seems that these events largely affected two distinctive features, nodulation and symbiosis (Young et al., 2011). In addition, WGD events cause novel disease-resistance and developmental mechanisms to emerge. It is thought that, during legume evolution, a rapid expansion occured in well-conserved disease resistance genes and this expansion was followed by a contraction. Some resistance genes emerged after divergence of legumes. This dynamic pattern caused a much faster evolution of disease resistance genes than other genes as an essential need to adapt to dramatically changing environmental conditions. Moreover, it seems that, during domestication, especially the resistance genes, which directly involved in the plant-pathogen interaction pathway, were selected (Zheng et al., 2016).

Subsequent duplications also ocurred and shaped the genomes and evolution of characteristic traits of the legumes. For example, a second genome duplication took place about $13 \mathrm{Mya}$ and as a result, splitting of soybean occurred (Shoemaker et al., 1996). Therefore, one genomic region of M.truncatula or L. japonicus probably corresponds to two glycine regions. It is thought that these duplication events confer higher adaptability to rigorously changed environment and harsh conditions (Fawcett et al., 2009). One of the advantages that these duplication events provide the availability of nitrogen thanks to the evolution of nodulation and symbiosis regulative genes. Presence of nitrogen frees legumes of the need for the key constraint that other plants have to obtain, and thereby increases their adaptive capacity in more drastic environments (Cannon et al., 2009). In addition to this naturally occurred selection, artificial selection also shaped the legume genomes. When wild and cultivated soybean genomes compared, it is revealed that differentiated genome regions in cultivated soybean correlates with variation in harvest index and yield (Huang et al., 2008).

Sequenced legume genomes reflect the significant similarity between legume groups. It is reported in a more recent study that in Lotus and Medicago genomes there are many colinear, extensive syntenic regions and that gene densities are relatively homogeneous (Cannon et al., 2006). Legumes have higher numbers and increased complexity in the gene families such as lipoxygenases (Shin et al., 2008). LysM (Lysin motif) receptor kinases (Zhang et al., 2007) and enzymes that function in flavonoid synthesis (Young et al., 2011). Furthermore, soybean, Lotus and Medicago genomes harbour high numbers of F-box domain protein coding genes and Medicago genome contains special cysteine-rich peptides coding gene family. It is noteworthy that the products of these genes function especially in nodules (Young \& Bharti, 2012). The genomes of some legumes contain distinct genes observed only in legume genomes. For example, Medicago truncatula genome express 566 defensin-like genes which have unique cis-element motifs in the upstream 1,000 bp promoter regions of nodule cysteine rich family (Nallu et al., 2013). These genes expressed only in nodules at various stages of development and sometimes have important function in rhizobial biology. Other well known nodulation related proteins are nodulins, early nodulation proteins (ENOD 16 and 8), ascorbate metabolic enzymes, and putative rhizobial effectors (Rathi et al., 2016). Schmutz et al. (2010), sequenced G. max genome and identified 283 putative legume-specific gene families which are absent in grapevine, poplar, Arabidopsis, papaya and grass genomes. Therefore, the analysis of the functions of these specific gene families enables to understand the legume biology more comprehensively. In addition to gene gaining, throughout their evolution, legumes have lost some genes known as legume lost genes (LLGs). These lost genes, like the gained genes, have also contributed to evolution of symbiotic relationship with rhizobia. For example, it is reported that 34 LLGs might have lost in, one of the sub-family of leguminosae, Papilionoideae family and orthologs of 21 LLGs in nonlegume plants function in plant defence mechanisms. Accordingly, it seems that gene lose has also a considerable impact on distict features of Papilionoidae family (Gu et al., 2016).

The genetic diversity and taxonomic structure of Glycine species have been investigated and their results suggest that wild soybean should be conserved to maintain the genetic diversity of soybean (Wang et al., 2016; Wang et al., 2015a; Wang et al., 2015b). Wild crop relatives are more genetically diverse than their domesticated counterparts so resequencing is limited in point of capturing many types of structural variation. Besides, presence-absence variation and copy number variation that are generally associated with agronomic traits, may also be missed. In order to capture the majority of genetic diversity within species, de novo construction of a pan-genome for species which consists of a core genome shared among individuals is compulsory. Li et al. (2014), by sequencing and assembling seven G. soja accessions de novo, constructed a pan-genome with the aim of completely characterizing the genomic content and molecular evolutionary history of G. soja. In this pan-genome, nonessential gene set was found to have evolved more promptly and be more variable than the core gene set and also genes under selection displayed relatively little overlap between the seven G. soja lineages showing that local adaptation may have affected non-overlapping sets of genes. As a consequence, researchers considered that the divergence time between G. soja and G. max was nearly three times earlier than a previous consideration (Bohra \& Singh, 2015).

\section{Conclusion}

The research summarized in this review, clarify the potantial of legume plants for human nutrition because of their remarkable molecular content, health benefits, nutritional value and distinctive genomic features. Soybean and derivative food products are prominent in the world. Newly developed technologies such as next generation sequencing, will serve as powerful tools to understand new features and advantages of these plants. Revealing the genomic potentials and characteristic properties of legumes will help to improve their nutritional capacity and resistancy to harsh conditions. However, still, there is a great need for collaborations of agronomists, plant geneticist and bioinformaticions to utilize the gigantic data and develop new traits in the context of nutritional value.

\section{References}

Abete, I., Astrup, A., Martinez, J. A., Thorsdottir, I., \& Zulet, M. A. (2010). Obesity and the metabolic syndrome: role of different dietary macronutrient distribution patterns and specific nutritional 
components on weight loss and maintenance. Nutrition Reviews, 68(4), 214-231. http://dx.doi.org/10.1111/j.1753-4887.2010.00280.x. PMid:20416018.

Abeysekara, S., Chilibeck, P. D., Vatanparast, H., \& Zello, G. A. (2012). A pulse-based diet is effective for reducing total and LDL-cholesterol in older adults. British Journal of Nutrition, 108(Suppl 1), S103-S10. http://dx.doi.org/10.1017/S0007114512000748. PMid:22916805.

Afshin, A., Micha, R., Khatibzadeh, S., \& Mozaffarian, D. (2014). Consumption of nuts and legumes and risk of incident ischemic heart disease, stroke, and diabetes: a systematic review and meta-analysis. The American Journal of Clinical Nutrition, 100(1), 278-288. http:// dx.doi.org/10.3945/ajcn.113.076901. PMid:24898241.

American Diabetes Association - ADA. (2011). Diagnosis and classification of diabetes mellitus. Arlington: ADA.

Amoroso, L. (2016). The second international conference on nutrition: implications for hidden hunger. World Review of Nutrition and Dietetics, 115, 142-152. http://dx.doi.org/10.1159/000442100. PMid:27197665.

Arnoldi, A., Boschin, G., Zanoni, C., \& Lammi, C. (2015). The health benefits of sweet lupin seed flours and isolated proteins. Journal of Functional Foods, 18, 550-563. http://dx.doi.org/10.1016/j. jff.2015.08.012.

Aune, D., Stefani, E., Ronco, A., Boffetta, P., Deneo-Pellegrini, H., Acosta, G., \& Mendilaharsu, M. (2009). Legume intake and the risk of cancer: a multisite case-control study in Uruguay. Cancer Causes \& Control, 20(9), 1605-1615. http://dx.doi.org/10.1007/ s10552-009-9406-z. PMid:19653110.

Bazzano, L. A., He, J., Ogden, L. G., Loria, C., Vupputuri, S., Myers, L., \& Whelton, P. K. (2001). Legume consumption and risk of coronary heart disease in US men and women: NHANES I Epidemiologic Follow-up Study. Archives of Internal Medicine, 161(21), 2573-2578. http://dx.doi.org/10.1001/archinte.161.21.2573. PMid:11718588.

Bennink, M. R. (2002). Consumption of black beans and navy beans (Phaseolus vulgaris) reduced azoxymethane-induced colon cancer in rats. Nutrition and Cancer, 44(1), 60-65. http://dx.doi.org/10.1207/ S15327914NC441_8. PMid:12672642.

Bohra, A. (2013). Emerging paradigms in genomics-based crop improvement. The Scientific World Journal, 2013, 585467. http:// dx.doi.org/10.1155/2013/585467. PMid:24348171.

Bohra, A., \& Singh, N. P. (2015). Whole genome sequences in pulse crops: a global community resource to expedite translational genomics and knowledge-based crop improvement. Biotechnology Letters, 37(8), 1529-1539. http://dx.doi.org/10.1007/s10529-0151836-y. PMid:25851953.

Bohra, A., Pandey, M. K., Jha, U. C., Singh, B., Singh, I. P., Datta, D., Chaturvedi, S. K., Nadarajan, N., \& Varshney, R. K. (2014). Genomicsassisted breeding in four major pulse crops of developing countries: present status and prospects. Theoretical and Applied Genetics, 127(6), 1263-1291. http://dx.doi.org/10.1007/s00122-014-2301-3. PMid:24710822.

Bohra, A., Sahrawat, K. L., Kumar, S., Joshi, R., Parihar, A. K., Singh, U., Singh, D., \& Singh, N. P. (2015). Genetics- and genomics-based interventions for nutritional enhancement of grain legume crops: status and outlook. Journal of Applied Genetics, 56(2), 151-161. http://dx.doi.org/10.1007/s13353-014-0268-z. PMid:25592547.

Boland, C. R., Martin, M. A., \& Goldstein, I. J. (1992). Lectin reactivities as intermediate biomarkers in premalignant colorectal epithelium. Journal of Cellular Biochemistry, 50(S16G), 103-109. http://dx.doi. org/10.1002/jcb.240501119. PMid:1469891.
Caccialupi, P., Ceci, L. R., Siciliano, R. A., Pignone, D., Clemente, A., \& Sonnante, G. (2010). Bowman-birk inhibitors in lentil: Heterologous expression, functional characterisation and anti-proliferative properties in human colon cancer cells. Food Chemistry, 120(4), 1058-1066. http://dx.doi.org/10.1016/j.foodchem.2009.11.051.

Calle, E. E., Rodriguez, C., Walker-Thurmond, K., \& Thun, M. J. (2003). Overweight, obesity, and mortality from cancer in a prospectively studied cohort of US adults. The New England Journal of Medicine, 348(17), 1625-1638. http://dx.doi.org/10.1056/NEJMoa021423. PMid:12711737.

Cannon, S. B., May, G. D., \& Jackson, S. A. (2009). Three sequenced legume genomes and many crop species: rich opportunities for translational genomics. Plant Physiology, 151(3), 970-977. http:// dx.doi.org/10.1104/pp.109.144659. PMid:19759344.

Cannon, S. B., Sterck, L., Rombauts, S., Sato, S., Cheung, F., Gouzy, J., Wang, X., Mudge, J., Vasdewani, J., Schiex, T., Spannagl, M., Monaghan, E., Nicholson, C., Humphray, S. J., Schoof, H., Mayer, K. F., Rogers, J., Quétier, F., Oldroyd, G. E., Debellé, F., Cook, D. R., Retzel, E. F., Roe, B. A., Town, C. D., Tabata, S., Van de Peer, Y., \& Young, N. D. (2006). Legume genome evolution viewed through the Medicago truncatula and Lotus japonicus genomes. Proceedings of the National Academy of Sciences of the United States of America, 103(40), 14959-14964. http://dx.doi.org/10.1073/pnas.0603228103. PMid:17003129.

Celleno, L., Tolaini, M. V., D’Amore, A., Perricone, N. V., \& Preuss, H. G. (2007). A dietary supplement containing standardized Phaseolus vulgaris extract influences body composition of overweight men and women. International Journal of Medical Sciences, 4(1), 45-52. http://dx.doi.org/10.7150/ijms.4.45. PMid:17299581.

Chan, Y. S., Zhang, Y. B., \& Ng, T. B. (2013). Brown kidney bean bowman-birk trypsin inhibitor is heat and ph stable and exhibits anti-proliferative activity. Applied Biochemistry and Biotechnology, 169(4), 1306-1314. http://dx.doi.org/10.1007/s12010-012-9998-8. PMid:23306898.

Chang, W. W., Yu, C. Y., Lin, T. W., Wang, P. H., \& Tsai, Y. C. (2006). Soyasaponin I decreases the expression of alpha2,3-linked sialic acid on the cell surface and suppresses the metastatic potential of B16F10 melanoma cells. Biochemical and Biophysical Research Communications, 341(2), 614-619. http://dx.doi.org/10.1016/j. bbrc.2005.12.216. PMid:16427612.

Chen, L., Magliano, D. J., \& Zimmet, P. Z. (2011). The worldwide epidemiology of type 2 diabetes mellitus--present and future perspectives. Nature Reviews. Endocrinology, 8(4), 228-236. http:// dx.doi.org/10.1038/nrendo.2011.183. PMid:22064493.

Chen, Y. W., Huang, S. C., Lin-Shiau, S. Y., \& Lin, J. K. (2005). Bowmanbirk inhibitor abates proteasome function and suppresses the proliferation of MCF7 breast cancer cells through accumulation of MAP kinase phosphatase-1. Carcinogenesis, 26(7), 1296-1306. http://dx.doi.org/10.1093/carcin/bgi062. PMid:15746161.

Cooke, G. M. (2006). A review of the animal models used to investigate the health benefits of soy isoflavones. Journal of AOAC International, 89(4), 1215-1227. PMid:16918038.

Dam, S., Dyrlund, T. F., Ussatjuk, A., Jochimsen, B., Nielsen, K., Goffard, N., Ventosa, M., Lorentzen, A., Gupta, V., Andersen, S. U., Enghild, J. J., Ronson, C. W., Roepstorff, P., \& Stougaard, J. (2014). Proteome reference maps of the Lotus japonicus nodule and root. Proteomics, 14(2-3), 230-240. http://dx.doi.org/10.1002/pmic.201300353. PMid:24293220.

Diapari, M., Sindhu, A., Bett, K., Deokar, A., Warkentin, T. D., \& Tar'an, B. (2014). Genetic diversity and association mapping of iron and 
zinc concentrations in chickpea (Cicer arietinum L.). Genome, 57(8), 459-468. http://dx.doi.org/10.1139/gen-2014-0108. PMid:25434748.

Dita, M. A., Rispail, N., Prats, E., Rubiales, D., \& Singh, K. B. (2006). Biotechnology approaches to overcome biotic and abiotic stress constraints in legumes. Euphytica, 147(1-2), 1-24. http://dx.doi. org/10.1007/s10681-006-6156-9.

Dong, J. Y., Zhang, L., Zhang, Y. H., \& Qin, L. Q. (2011). Dietary glycaemic index and glycaemic load in relation to the risk of type 2 diabetes: a meta-analysis of prospective cohort studies. British Journal of Nutrition, 106(11), 1649-1654. http://dx.doi.org/10.1017/ S000711451100540X. PMid:22017823.

Duranti, M. (2006). Grain legume proteins and nutraceutical properties. Fitoterapia, 77(2), 67-82. http://dx.doi.org/10.1016/j.fitote.2005.11.008. PMid:16406359.

Ellington, A. A., Berhow, M. A., \& Singletary, K. W. (2006). Inhibition of Akt signaling and enhanced ERK1/2 activity are involved in induction of macroautophagy by triterpenoid B-group soyasaponins in colon cancer cells. Carcinogenesis, 27(2), 298-306. http://dx.doi. org/10.1093/carcin/bgi214. PMid:16113053.

Fawcett, J. A., Maere, S., \& Van de Peer, Y. (2009). Plants with double genomes might have had a better chance to survive the CretaceousTertiary extinction event. Proceedings of the National Academy of Sciences of the United States of America, 106(14), 5737-5742. http:// dx.doi.org/10.1073/pnas.0900906106. PMid:19325131.

Feregrino-Perez, A. A., Berumen, L. C., Garcia-Alcocer, G., GuevaraGonzalez, R. G., Ramos-Gomez, M., Reynoso-Camacho, R., Acosta-Gallegos, J. A., \& Loarca-Pina, G. (2008). Composition and chemopreventive effect of polysaccharides from common beans (Phaseolus vulgaris L.) on azoxymethane-induced colon cancer. Journal of Agricultural and Food Chemistry, 56(18), 8737-8744. http://dx.doi.org/10.1021/jf8007162. PMid:18754663.

Flight, I., \& Clifton, P. (2006). Cereal grains and legumes in the prevention of coronary heart disease and stroke: a review of the literature. European Journal of Clinical Nutrition, 60(10), 1145-1159. http:// dx.doi.org/10.1038/sj.ejcn.1602435. PMid:16670693.

Galvez, A. F., Chen, N., Macasieb, J., \& Lumen, B. O. (2001). Chemopreventive property of a soybean peptide (lunasin) that binds to deacetylated histones and inhibits acetylation. Cancer Research, 61(20), 7473-7478. PMid:11606382.

Gepts, P., Beavis, W. D., Brummer, E. C., Shoemaker, R. C., Stalker, H. T., Weeden, N. F., \& Young, N. D. (2005). Legumes as a model plant family. Genomics for food and feed report of the cross-legume advances through genomics conference. Plant Physiology, 137(4), 1228-1235. http://dx.doi.org/10.1104/pp.105.060871. PMid:15824285.

Gu, Y. Z., Xing, S. L., \& He, C. Y. (2016). Genome-Wide Analysis Indicates Lineage-Specific Gene Loss during Papilionoideae Evolution. Genome Biology and Evolution, 8(3), 635-648. http://dx.doi.org/10.1093/gbe/ evw021. PMid:26868598.

Gupta, S. N. N., Legumes in Omic Era: retrospects and prospects. In: S. N. N. Gupta, \& D. S. Gupta (Eds.), Legumes in the Omic Era. New York: Springer; 2014: 1-4. http://dx.doi.org/10.1007/978-14614-8370-0_1.

Hammouda, F. M., \& Ahmed, Z. F. (1962). A phytochemical study of the seeds of Pisum sativum L. II. Chemical investigation of the fixed oil of the seeds. Bollettino Chimico Farmaceutico, 101, 752761. PMid:13952416.

Harland, B. F., \& Morris, E. R. (1995). Phytate - a good or a bad food component. Nutrition Research (New York, N.Y.), 15(5), 733-754. http://dx.doi.org/10.1016/0271-5317(95)00040-P.
Hermsdorff, H. H. M., Zulet, M. A., Abete, I., \& Martinez, J. A. (2011). A legume-based hypocaloric diet reduces proinflammatory status and improves metabolic features in overweight/obese subjects. European Journal of Nutrition, 50(1), 61-69. http://dx.doi.org/10.1007/ s00394-010-0115-x. PMid:20499072.

Hernández-Ledesma, B., Hsieh, C. C., \& Lumen, B. O. (2009). Lunasin, a novel seed peptide for cancer prevention. Peptides, 30(2), 426-430. http://dx.doi.org/10.1016/j.peptides.2008.11.002. PMid:19056440.

Hernández-Ledesma, B., Hsieh, C. C., \& Lumen, B. O. (2011). Relationship between lunasin's sequence and its inhibitory activity of histones H3 and H4 acetylation. Molecular Nutrition \& Food Research, 55(7), 989-998. http://dx.doi.org/10.1002/mnfr.201000632. PMid:21618425.

Herszényi, L., Hritz, I., Lakatos, G., Varga, M. Z., \& Tulassay, Z. (2012). The behavior of matrix metalloproteinases and their inhibitors in colorectal cancer. International Journal of Molecular Sciences, 13(10), 13240-13263. http://dx.doi.org/10.3390/ijms131013240. PMid:23202950.

Hsieh, C. C., Martínez-Villaluenga, C., Lumen, B. O., \& HernándezLedesma, B. (2018). Updating the research on the chemopreventive and therapeutic role of the peptide lunasin. Journal of the Science of Food and Agriculture, 98(6), 2070-2079. PMid:28990666.

Huang, Z. W., Zhao, T. J., Yu, D. Y., Chen, S. Y., Gai, J. Y. (2008). Correlation and QTL mapping of biomass accumulation, apparent harvest index, and yield in soybean. Acta Agronomica Sinica, 34(6), 944-951. http://dx.doi.org/10.3724/SP.J.1006.2008.00944.

James, C. (2009). International service for the acquisition of agri-biotech applications - Global status of commercialized biotech/GM crops. Ithaca: ISAAA.

Jemal, A., Bray, F., Center, M. M., Ferlay, J., Ward, E., \& Forman, D. (2011). Global cancer statistics. CA: A Cancer Journal for Clinicians, 61(2), 69-90. http://dx.doi.org/10.3322/caac.20107. PMid:21296855.

Jenkins, D. J., Kendall, C. W., Augustin, L. S., Mitchell, S., SahyePudaruth, S., Blanco Mejia, S., Chiavaroli, L., Mirrahimi, A., Ireland, C., Bashyam, B., Vidgen, E., Souza, R. J., Sievenpiper, J. L., Coveney, J., Leiter, L. A., \& Josse, R. G. (2012). Effect of legumes as part of a low glycemic index diet on glycemic control and cardiovascular risk factors in type 2 diabetes mellitus a randomized controlled trial. Archives of Internal Medicine, 172(21), 1653-1660. http://dx.doi. org/10.1001/2013.jamainternmed.70. PMid:23089999.

Jeong, H. J., Jeong, J. B., Kim, D. S., \& Lumen, B. O. (2007). Inhibition of core histone acetylation by the cancer preventive peptide lunasin. Journal of Agricultural and Food Chemistry, 55(3), 632-637. http:// dx.doi.org/10.1021/jf062405u. PMid:17263453.

Jeong, H. J., Lam, Y., \& Lumen, B. O. (2002). Barley lunasin suppresses ras-induced colony formation and inhibits core histone acetylation in mammalian cells. Journal of Agricultural and Food Chemistry, 50(21), 5903-5908. http://dx.doi.org/10.1021/jf0256945. PMid:12358457.

Jeong, H. J., Lee, J. R., Jeong, J. B., Park, J. H., Cheong, Y. K., \& Lumen, B. O. (2009). the cancer preventive seed peptide lunasin from rye is bioavailable and bioactive. Nutrition and Cancer, 61(5), 680-686. http://dx.doi.org/10.1080/01635580902850082. PMid:19838942.

Jeong, J. B., Lumen, B. O., \& Jeong, H. J. (2010). Lunasin peptide purified from Solanum nigrum L. protects DNA from oxidative damage by suppressing the generation of hydroxyl radical via blocking fenton reaction. Cancer Letters, 293(1), 58-64. http://dx.doi.org/10.1016/j. canlet.2009.12.019. PMid:20083341.

Jimenez-Cruz, A., Bacardi-Gascon, M., Turnbull, W. H., Rosales-Garay, P., \& Severino-Lugo, I. (2003). A flexible, low-glycemic index Mexican-style diet in overweight and obese subjects with type 2 diabetes improves metabolic parameters during a 6-week treatment 
period. Diabetes Care, 26(7), 1967-1970. http://dx.doi.org/10.2337/ diacare.26.7.1967. PMid:12832297.

Jukanti, A. K., Gaur, P. M., Gowda, C. L., \& Chibbar, R. N. (2012). Nutritional quality and health benefits of chickpea (Cicer arietinum L.): a review. British Journal of Nutrition, 108(S1, Suppl 1), S11-S26. http://dx.doi.org/10.1017/S0007114512000797. PMid:22916806.

Kalogeropoulos, N., Chiou, A., Ioannou, M., Karathanos, V. T., Hassapidou, M., \& Andrikopoulos, N. K. (2010). Nutritional evaluation and bioactive microconstituents (phytosterols, tocopherols, polyphenols, triterpenic acids) in cooked dry legumes usually consumed in the Mediterranean countries. Food Chemistry, 121(3), 682-690. http:// dx.doi.org/10.1016/j.foodchem.2010.01.005.

Kennedy, A. R. (1994). Prevention of carcinogenesis by protease inhibitors. Cancer Research, 54(7, Suppl), 1999s-2005s. PMid:8137328.

Kinjo, J., Hatakeyama, M., Udayama, M., Tsutanaga, Y., Yamashita, M., Nohara, T., Yoshiki, Y., \& Okubo, K. (1998). HPLC profile analysis of oleanene-glucuronides in several edible beans. Bioscience, Biotechnology, and Biochemistry, 62(3), 429-433. http://dx.doi. org/10.1271/bbb.62.429. PMid:9571771.

Klein, M. A., \& Grusak, M. A. (2009). Identification of nutrient and physical seed trait QTL in the model legume Lotus japonicus. Genome, 52(8), 677-691. http://dx.doi.org/10.1139/G09-039. PMid:19767898.

Kosová, K., Vitamvas, P., Prasil, I. T., \& Renaut, J. (2011). Plant proteome changes under abiotic stress - Contribution of proteomics studies to understanding plant stress response. Journal of Proteomics, 74(8), 1301-1322. http://dx.doi.org/10.1016/j.jprot.2011.02.006. PMid:21329772.

Kouris-Blazos, A., \& Belski, R. (2016). Health benefits of legumes and pulses with a focus on Australian sweet lupins. Asia Pacific Journal of Clinical Nutrition, 25(1), 1-17. PMid:26965756.

Larrainzar, E., Wienkoop, S., Weckwerth, W., Ladrera, R., Arrese-Igor, C., \& Gonzalez, E. M. (2007). Medicago truncatula root nodule proteome analysis reveals differential plant and bacteroid responses to drought stress. Plant Physiology, 144(3), 1495-1507. http://dx.doi. org/10.1104/pp.107.101618. PMid:17545507.

Lei, Z., Elmer, A. M., Watson, B. S., Dixon, R. A., Mendes, P. J., \& Sumner, L. W. (2005). A two-dimensional electrophoresis proteomic reference map and systematic identification of 1367 proteins from a cell suspension culture of the model legume Medicago truncatula. Molecular \& Cellular Proteomics, 4(11), 1812-1825. http://dx.doi. org/10.1074/mcp.D500005-MCP200. PMid:16048909.

Li, J. T., Zhang, J. L., He, H., Ma, Z. L., Nie, Z. K., Wang, Z. Z., \& Xu, X. G. (2013). Apoptosis in human hepatoma HepG2 cells induced by corn peptides and its anti-tumor efficacy in $\mathrm{H} 22$ tumor bearing mice. Food and Chemical Toxicology, 51, 297-305. http://dx.doi. org/10.1016/j.fct.2012.09.038. PMid:23063592.

Li, L. J., Lv, Y. H., Xu, L., \& Zheng, Q. S. (2015). Quantitative efficacy of soy isoflavones on menopausal hot flashes. British Journal of Clinical Pharmacology, 79(4), 593-604. http://dx.doi.org/10.1111/ bcp.12533. PMid:25316502.

Li, Y. H., Zhou, G. Y., Ma, J. X., Jiang, W. K., Jin, L. G., Zhang, Z. H., Guo, Y., Zhang, J. B., Sui, Y., Zheng, L. T., Zhang, S. S., Zuo, Q. Y., Shi, X. H., Li, Y. F., Zhang, W. K., Hu, Y. Y., Kong, G. Y., Hong, H. L., Tan, B., Song, J., Liu, Z. X., Wang, Y. S., Ruan, H., Yeung, C. K. L., Liu, J., Wang, H. L., Zhang, L. J., Guan, R. X., Wang, K. J., Li, W. B., Chen, S. Y., Chang, R. Z., Jiang, Z., Jackson, S. A., Li, R. Q., \& Qiu, L. J. (2014). De novo assembly of soybean wild relatives for pan-genome analysis of diversity and agronomic traits. Nature Biotechnology, 32(10), 1045-1052. http://dx.doi.org/10.1038/nbt.2979. PMid:25218520.
Liener, I. E. (1991). From soybeans to lectins - a trail of research revisited. Carbohydrate Research, 213, 1-5. http://dx.doi.org/10.1016/S00086215(00)90592-5. PMid:1933931.

Lima, A. I. G., Mota, J., Monteiro, S. A. V. S., \& Ferreira, R. M. S. B. (2016). Legume seeds and colorectal cancer revisited: Protease inhibitors reduce MMP-9 activity and colon cancer cell migration. Food Chemistry, 197(Pt A), 30-38. http://dx.doi.org/10.1016/j. foodchem.2015.10.063. PMid:26616921.

López, P. M. G., Mora, P. G., Wysocka, W., Maiztegui, B., Alzugaray, M. E., Zotto, H., \& Borelli, M. I. (2004). Quinolizidine alkaloids isolated from Lupinus species enhance insulin secretion. European Journal of Pharmacology, 504(1-2), 139-142. http://dx.doi.org/10.1016/j. ejphar.2004.09.008. PMid:15507230.

López-Barrios, L., Gutierrez-Uribe, J. A., \& Serna-Saldivar, S. O. (2014). Bioactive peptides and hydrolysates from pulses and their potential use as functional ingredients. Journal of Food Science, 79(3), R273-R83. http://dx.doi.org/10.1111/1750-3841.12365. PMid:24547749.

Lumen, B. O. (2005). Lunasin: a cancer-preventive soy peptide. Nutrition Reviews, 63(1), 16-21. http://dx.doi.org/10.1111/j.1753-4887.2005. tb00106.x. PMid:15730231.

Mackay, I., \& Powell, W. (2007). Methods for linkage disequilibrium mapping in crops. Trends in Plant Science, 12(2), 57-63. http://dx.doi. org/10.1016/j.tplants.2006.12.001. PMid:17224302.

Malaguti, M., Dinelli, G., Leoncini, E., Bregola, V., Bosi, S., Cicero, A. F., \& Hrelia, S. (2014). Bioactive peptides in cereals and legumes: agronomical, biochemical and clinical aspects. International Journal of Molecular Sciences, 15(11), 21120-21135. http://dx.doi.org/10.3390/ ijms151121120. PMid:25405741.

Manach, C., Williamson, G., Morand, C., Scalbert, A., \& Remesy, C. (2005). Bioavailability and bioefficacy of polyphenols in humans. I. Review of 97 bioavailability studies. The American Journal of Clinical Nutrition, 81(1 Suppl), 230S-242S. http://dx.doi.org/10.1093/ ajcn/81.1.230S. PMid:15640486.

Markle, B., May, E. J., \& Majumdar, A. P. N. (2010). Do nutraceutics play a role in the prevention and treatment of colorectal cancer? Cancer and Metastasis Reviews, 29(3), 395-404. http://dx.doi.org/10.1007/ s10555-010-9234-3. PMid:20717706.

Martínez, M. E., Thomson, C. A., \& Smith-Warner, S. A. (2006). Soy and breast cancer: the controversy continues. Journal of the National Cancer Institute, 98(7), 430-431. http://dx.doi.org/10.1093/jnci/ djj128. PMid:16595771.

Maruyama, C., Araki, R., Kawamura, M., Kondo, N., Kigawa, M., Kawai, Y., Takanami, Y., Miyashita, K., \& Shimomitsu, T. (2008). Azuki bean juice lowers serum triglyceride concentrations in healthy young women. Journal of Clinical Biochemistry and Nutrition, 43(1), 19-25. http://dx.doi.org/10.3164/jcbn.2008039. PMid:18648655.

Marventano, S., Pulido, M. I., Sanchez-Gonzalez, C., Godos, J., Speciani, A., Galvano, F., \& Grosso, G. (2017). Legume consumption and CVD risk: a systematic review and meta-analysis. Public Health Nutrition, 20(2), 245-254. http://dx.doi.org/10.1017/S1368980016002299. PMid:28077199.

Mathers, J. C. (2002). Pulses and carcinogenesis: potential for the prevention of colon, breast and other cancers. British Journal of Nutrition, 88(Suppl 3), S273-S279. http://dx.doi.org/10.1079/ BJN2002717. PMid:12498627.

Mejia, E. G., \& Dia, V. P. (2010). The role of nutraceutical proteins and peptides in apoptosis, angiogenesis, and metastasis of cancer cells. Cancer and Metastasis Reviews, 29(3), 511-528. http://dx.doi. org/10.1007/s10555-010-9241-4. PMid:20714786. 
Messina, M. J. (1999). Legumes and soybeans: overview of their nutritional profiles and health effects. The American Journal of Clinical Nutrition, 70(3, Suppl), 439S-450S. http://dx.doi.org/10.1093/ ajcn/70.3.439s. PMid:10479216.

Messina, M., McCaskill-Stevens, W., \& Lampe, J. W. (2006). Addressing the soy and breast cancer relationship: review, commentary, and workshop proceedings. Journal of the National Cancer Institute, 98(18), 1275-1284. http://dx.doi.org/10.1093/jnci/djj356. PMid:16985246.

Mitchell-Olds, T. (2010). Complex-trait analysis in plants. Genome Biology, 11(4), 113. http://dx.doi.org/10.1186/gb-2010-11-4-113. PMid:20409352.

Mollard, R. C., Luhovyy, B. L., Panahi, S., Nunez, M., Hanley, A., \& Anderson, G. H. (2012). Regular consumption of pulses for 8 weeks reduces metabolic syndrome risk factors in overweight and obese adults. British Journal of Nutrition, 108(S1, Suppl 1), S111-S122. http://dx.doi.org/10.1017/S0007114512000712. PMid:22916807.

Möller, N. P., Scholz-Ahrens, K. E., Roos, N., \& Schrezenmeir, J. (2008). Bioactive peptides and proteins from foods: indication for health effects. European Journal of Nutrition, 47(4), 171-182. http://dx.doi. org/10.1007/s00394-008-0710-2. PMid:18506385.

Muzquiz, M., Varela, A., Burbano, C., Cuadrado, C., Guillamon, E., \& Pedrosa, M. M. (2012). Bioactive compounds in legumes: pronutritive and antinutritive actions. Implications for nutrition and health. Phytochemistry Reviews, 11(2-3), 227-244. http://dx.doi. org/10.1007/s11101-012-9233-9.

Nagura, J., Iso, H., Watanabe, Y., Maruyama, K., Date, C., Toyoshima, H., Yamamoto, A., Kikuchi, S., Koizumi, A., Kondo, T., Wada, Y., Inaba, Y., Tamakoshi, A., Grp, J. S., \& JACC Study Group. (2009). Fruit, vegetable and bean intake and mortality from cardiovascular disease among Japanese men and women: the JACC Study. British Journal of Nutrition, 102(2), 285-292. http://dx.doi.org/10.1017/ S0007114508143586. PMid:19138438.

Nallu, S., Silverstein, K. A. T., Samac, D. A., Bucciarelli, B., Vance, C. P., \& VandenBosch, K. A. (2013). Regulatory patterns of a large family of defensin-like genes expressed in nodules of Medicago truncatula. PLoS One, 8(4), e60355. http://dx.doi.org/10.1371/ journal.pone.0060355. PMid:23573247.

Natarajan, S., Luthria, D., Bae, H., Lakshman, D., \& Mitra, A. (2013). Transgenic soybeans and soybean protein analysis: an overview. Journal of Agricultural and Food Chemistry, 61(48), 11736-11743. http://dx.doi.org/10.1021/jf402148e. PMid:24099420.

Nestel, P., Cehun, M., \& Chronopoulos, A. (2004). Effects of long-term consumption and single meals of chickpeas on plasma glucose, insulin, and triacylglycerol concentrations. The American Journal of Clinical Nutrition, 79(3), 390-395. http://dx.doi.org/10.1093/ ajcn/79.3.390. PMid:14985212.

Nilsson, A., Johansson, E., Ekstrom, L., \& Bjorck, I. (2013). Effects of a brown beans evening meal on metabolic risk markers and appetite regulating hormones at a subsequent standardized breakfast: a randomized cross-over study. PLoS One, 8(4), e59985. http://dx.doi. org/10.1371/journal.pone.0059985. PMid:23577078.

Obata, T., \& Fernie, A. R. (2012). The use of metabolomics to dissect plant responses to abiotic stresses. Cellular and Molecular Life Sciences, 69(19), 3225-3243. http://dx.doi.org/10.1007/s00018-0121091-5. PMid:22885821.

Ortiz-Martinez, M., Winkler, R., \& Garcia-Lara, S. (2014). Preventive and therapeutic potential of peptides from cereals against cancer. Journal of Proteomics, 111, 165-183. http://dx.doi.org/10.1016/j. jprot.2014.03.044. PMid:24727098.

Park, J. H., Jeong, H. J., \& de Lumen, B. O. (2005). Contents and bioactivities of lunasin, Bowman-Birk inhibitor, and isoflavones in soybean seed. Journal of Agricultural and Food Chemistry, 53(20), 7686-7690. http://dx.doi.org/10.1021/jf0506481. PMid:16190617.

Pfeil, B. E., Schlueter, J. A., Shoemaker, R. C., \& Doyle, J. J. (2005). Placing paleopolyploidy in relation to taxon divergence: a phylogenetic analysis in legumes using 39 gene families. Systematic Biology, 54(3), 441-454. http://dx.doi.org/10.1080/10635150590945359. PMid:16012110.

Poland, J. A., \& Rife, T. W. (2012). Genotyping-by-sequencing for plant breeding and genetics. Plant Genome-Us, 5(3), 92-102. http://dx.doi. org/10.3835/plantgenome2012.05.0005.

Ramamurthy, R. K., Jedlicka, J., Graef, G. L., \& Waters, B. M. (2014). Identification of new QTLs for seed mineral, cysteine, and methionine concentrations in soybean [Glycine max (L.) Merr.]. Molecular Breeding, 34(2), 431-445. http://dx.doi.org/10.1007/s11032-014-0045-z.

Rathi, D., Gayen, D., Gayali, S., Chakraborty, S., \& Chakraborty, N. (2016). Legume proteomics: progress, prospects, and challenges. Proteomics, 16(2), 310-327. http://dx.doi.org/10.1002/pmic.201500257. PMid:26563903.

Rebello, C. J., Greenway, F. L., \& Finley, J. W. (2014). A review of the nutritional value of legumes and their effects on obesity and its related co-morbidities. Obesity Reviews, 15(5), 392-407. http:// dx.doi.org/10.1111/obr.12144. PMid:24433379.

Robles-Ramírez, M. C., Ramón-Gallegos, E., Reyes-Duarte, F. J., \& Mora-Escobedo, R. (2012). Effect of germinated soy protein on the growth of HeLa cervical cancer cells in female athymic mice. Nutrition and Cancer, 64(8), 1261-1268. http://dx.doi.org/10.1080 /01635581.2012.717681. PMid:23163854.

Rochfort, S., \& Panozzo, J. (2007). Phytochemicals for health, the role of pulses. Journal of Agricultural and Food Chemistry, 55(20), 7981-7994. http://dx.doi.org/10.1021/jf071704w. PMid:17784726.

Ruiz, R. G., Price, K. R., Arthur, A. E., Rose, M. E., Rhodes, M. J. C., \& Fenwick, R. G. (1996). Effect of soaking and cooking on the saponin content and composition of chickpeas (Cicer arietinum) and lentils (Lens culinaris). Journal of Agricultural and Food Chemistry, 44(6), 1526-1530. http://dx.doi.org/10.1021/jf950721v.

Saito, T., Sato, H., Virgona, N., Hagiwara, H., Kashiwagi, K., Suzuki, K., Asano, R., \& Yano, T. (2007). Negative growth control of osteosarcoma cell by Bowman-Birk protease inhibitor from soybean; involvement of connexin 43. Cancer Letters, 253(2), 249-257. http://dx.doi. org/10.1016/j.canlet.2007.01.021. PMid:17343982.

Sankaran, R. P., Huguet, T., \& Grusak, M. A. (2009). Identification of QTL affecting seed mineral concentrations and content in the model legume Medicago truncatula. Theoretical and Applied Genetics, 119(2), 241-253. http://dx.doi.org/10.1007/s00122-009-1033-2. PMid:19396421.

Scherling, C., Roscher, C., Giavalisco, P., Schulze, E. D., \& Weckwerth, W. (2010). Metabolomics Unravel Contrasting Effects of Biodiversity on the Performance of Individual Plant Species. PLoS One, 5(9), e12569. http://dx.doi.org/10.1371/journal.pone.0012569. PMid:20830202.

Schmutz, J., Cannon, S. B., Schlueter, J., Ma, J. X., Mitros, T., Nelson, W., Hyten, D. L., Song, Q. J., Thelen, J. J., Cheng, J. L., Xu, D., Hellsten, U., May, G. D., Yu, Y., Sakurai, T., Umezawa, T., Bhattacharyya, M. K., Sandhu, D., Valliyodan, B., Lindquist, E., Peto, M., Grant, D., Shu, S. Q., Goodstein, D., Barry, K., Futrell-Griggs, M., Abernathy, B., Du, J. C., Tian, Z. X., Zhu, L. C., Gill, N., Joshi, T., Libault, M., Sethuraman, A., Zhang, X. C., Shinozaki, K., Nguyen, H. T., Wing, R. A., Cregan, P., Specht, J., Grimwood, J., Rokhsar, D., Stacey, G., Shoemaker, R. C., \& Jackson, S. A. (2010). Genome sequence of the palaeopolyploid soybean. Nature, 463(7278), 178-183. http://dx.doi. org/10.1038/nature08670. PMid:20075913. 
Shi, J., Arunasalam, K., Yeung, D., Kakuda, Y., Mittal, G., \& Jiang, Y. M. (2004). Saponins from edible legumes: Chemistry, processing, and health benefits. Journal of Medicinal Food, 7(1), 67-78. http:// dx.doi.org/10.1089/109662004322984734. PMid:15117556.

Shin, J. H., Van, K., Kim, D. H., Kim, K., Jang, Y. E., Choi, B. S., Kim, M. Y., \& Lee, S. H. (2008). The lipoxygenase gene family: a genomic fossil of shared polyploidy between Glycine max and Medicago truncatula. BMC Plant Biology, 8(1), 133. http://dx.doi.org/10.1186/1471-22298-133. PMid:19105811.

Shoemaker, R. C., Polzin, K., Labate, J., Specht, J., Brummer, E. C., Olson, T., Young, N., Concibido, V., Wilcox, J., Tamulonis, J. P., Kochert, G., \& Boerma, H. R. (1996). Genome duplication in soybean (Glycine subgenus soja). Genetics, 144(1), 329-338. PMid:8878696.

Siegel, R., DeSantis, C., \& Jemal, A. (2014). Colorectal cancer statistics, 2014. CA: A Cancer Journal for Clinicians, 64(2), 104-117. http:// dx.doi.org/10.3322/caac.21220. PMid:24639052.

Sievenpiper, J. L., Kendall, C. W., Esfahani, A., Wong, J. M., Carleton, A. J., Jiang, H. Y., Bazinet, R. P., Vidgen, E., \& Jenkins, D. J. (2009). Effect of non-oil-seed pulses on glycaemic control: a systematic review and meta-analysis of randomised controlled experimental trials in people with and without diabetes. Diabetologia, 52(8), 1479-1495. http://dx.doi.org/10.1007/s00125-009-1395-7. PMid:19526214.

Simpson, H. C., Simpson, R. W., Lousley, S., Carter, R. D., Geekie, M., Hockaday, T. D., \& Mann, J. I. (1981). A high-carbohydrate leguminous fiber diet improves all aspects of diabetic control. Lancet, 1(8210), 1-5. http://dx.doi.org/10.1016/S0140-6736(81)90112-4. PMid:6109047.

Souza, L. D., Camargo, R., Demasi, M., Santana, J. M., Sa, C. M., \& Freitas, S. M. (2014). Effects of an anticarcinogenic bowman-birk protease inhibitor on purified 20S proteasome and MCF-7 breast cancer cells. PLoS One, 9(1), e86600. http://dx.doi.org/10.1371/ journal.pone.0086600. PMid:24475156.

Thorne, M. J., Thompson, L. U., \& Jenkins, D. J. A. (1983). Factors affecting starch digestibility and the glycemic response with special reference to legumes. The American Journal of Clinical Nutrition, 38(3), 481-488. http://dx.doi.org/10.1093/ajcn/38.3.481. PMid:6310984.

Trock, B. J., Hilakivi-Clarke, L., \& Clarke, R. (2006). Meta-analysis of soy intake and breast cancer risk. Journal of the National Cancer Institute, 98(7), 459-471. http://dx.doi.org/10.1093/jnci/djj102. PMid:16595782.

Varshney, R. K., Kudapa, H., Pazhamala, L., Chitikineni, A., Thudi, M., Bohra, A., Gaur, P. M., Janila, P., Fikre, A., Kimurto, P., \& Ellis, N. (2015). Translational genomics in agriculture: some examples in grain legumes. Critical Reviews in Plant Sciences, 34(1-3), 169-194. http://dx.doi.org/10.1080/07352689.2014.897909.

Varshney, R. K., Song, C., Saxena, R. K., Azam, S., Yu, S., Sharpe, A. G., Cannon, S., Baek, J., Rosen, B. D., Tar'an, B., Millan, T., Zhang, X. D., Ramsay, L. D., Iwata, A., Wang, Y., Nelson, W., Farmer, A. D., Gaur, P. M., Soderlund, C., Penmetsa, R. V., Xu, C. Y., Bharti, A. K., He, W. M., Winter, P., Zhao, S. C., Hane, J. K., Carrasquilla-Garcia, N., Condie, J. A., Upadhyaya, H. D., Luo, M. C., Thudi, M., Gowda, C. L. L., Singh, N. P., Lichtenzveig, J., Gali, K. K., Rubio, J., Nadarajan, N., Dolezel, J., Bansal, K. C., Xu, X., Edwards, D., Zhang, G. Y., Kahl, G., Gil, J., Singh, K. B., Datta, S. K., Jackson, S. A., Wang, J., \& Cook, D. R. (2013). Draft genome sequence of chickpea (Cicer arietinum) provides a resource for trait improvement. Nature Biotechnology, 31(3), 240-246. http://dx.doi.org/10.1038/nbt.2491. PMid:23354103.

Wanders, A. J., Borne, J. J. G. C., Graaf, C., Hulshof, T., Jonathan, M. C., Kristensen, M., Mars, M., Schols, H. A., \& Feskens, E. J. M. (2011). Effects of dietary fibre on subjective appetite, energy intake and body weight: a systematic review of randomized controlled trials. Obesity Reviews, 12(9), 724-739. PMid:21676152.

Wang, Y. S., Shahid, M. Q., \& Baloch, F. S. (2016). Phylogeographical studies of Glycine soja: implicating the refugium during the quaternary glacial period and large-scale expansion after the last glacial maximum. Turkish Journal of Agriculture and Forestry, 40, 825-838. http://dx.doi.org/10.3906/tar-1607-30.

Wang, Y. S., Shahid, M. Q., Ghouri, F., Baloch, F. S., Wang, Y., \& Huang, H. W. (2015a). Evaluation of the geographical pattern of genetic diversity of Glycine soja and Glycine max based on four single copy nuclear gene loci: for conservation of soybean germplasm. Biochemical Systematics and Ecology, 62, 229-235. http://dx.doi. org/10.1016/j.bse.2015.09.006.

Wang, Y. S., Shahid, M. Q., Huang, H. W., \& Wang, Y. (2015b). Nucleotide diversity patterns of three divergent soybean populations: evidences for population-dependent linkage disequilibrium and taxonomic status of Glycine gracilis. Ecology and Evolution, 5(18), 3969-3978. http://dx.doi.org/10.1002/ece3.1550. PMid:26442568.

Watson, B. S., Asirvatham, V. S., Wang, L. J., \& Sumner, L. W. (2003). Mapping the proteome of barrel medic (Medicago truncatula). Plant Physiology, 131(3), 1104-1123. http://dx.doi.org/10.1104/ pp.102.019034. PMid:12644662.

White, P. J., \& Broadley, M. R. (2009). Biofortification of crops with seven mineral elements often lacking in human diets - iron, zinc, copper, calcium, magnesium, selenium and iodine. The New Phytologist, 182(1), 49-84. http://dx.doi.org/10.1111/j.1469-8137.2008.02738.x. PMid:19192191.

Winham, D. M., \& Hutchins, A. M. (2007). Baked bean consumption reduces serum cholesterol in hypercholesterolemic adults. Nutrition Research, 27(7), 380-386. http://dx.doi.org/10.1016/j.nutres.2007.04.017.

Woldemichael, G. M., \& Wink, M. (2002). Triterpene glycosides of Lupinus angustifolius. Phytochemistry, 60(4), 323-327. http://dx.doi. org/10.1016/S0031-9422(02)00112-7. PMid:12031419.

Woldemichael, G. M., Montenegro, G., \& Timmermann, B. N. (2003). Triterpenoidal lupin saponins from the Chilean legume Lupinus oreophilus Phil. Phytochemistry, 63(8), 853-857. http://dx.doi. org/10.1016/S0031-9422(03)00328-5. PMid:12895529.

World Health Organization - WHO. (2011). Use of glycated haemoglobin (HbA1c) in the diagnosis of diabetes: abbreviated report of a WHO consultation. Geneva: World Health Organization.

Würschum, T. (2012). Mapping QTL for agronomic traits in breeding populations. Theoretical and Applied Genetics, 125(2), 201-210. http://dx.doi.org/10.1007/s00122-012-1887-6. PMid:22614179.

Young, N. D., \& Bharti, A. K. (2012). Genome-enabled insights into legume biology. Annual Review of Plant Biology, 63(1), 283-305. http:// dx.doi.org/10.1146/annurev-arplant-042110-103754. PMid:22404476.

Young, N. D., Debelle, F., Oldroyd, G. E. D., Geurts, R., Cannon, S. B., Udvardi, M. K., Benedito, V. A., Mayer, K. F. X., Gouzy, J., Schoof, H., Van de Peer, Y., Proost, S., Cook, D. R., Meyers, B. C., Spannagl, M., Cheung, F., De Mita, S., Krishnakumar, V., Gundlach, H., Zhou, S. G., Mudge, J., Bharti, A. K., Murray, J. D., Naoumkina, M. A., Rosen, B., Silverstein, K. A. T., Tang, H. B., Rombauts, S., Zhao, P. X., Zhou, P., Barbe, V., Bardou, P., Bechner, M., Bellec, A., Berger, A., Berges, H., Bidwell, S., Bisseling, T., Choisne, N., Couloux, A., Denny, R., Deshpande, S., Dai, X. B., Doyle, J. J., Dudez, A. M., Farmer, A. D., Fouteau, S., Franken, C., Gibelin, C., Gish, J., Goldstein, S., Gonzalez, A. J., Green, P. J., Hallab, A., Hartog, M., Hua, A., Humphray, S. J., Jeong, D. H., Jing, Y., Jocker, A., Kenton, S. M., Kim, D. J., Klee, K., Lai, H. S., Lang, C. T., Lin, S. P., Macmil, S. L., Magdelenat, G., Matthews, L., McCorrison, J., Monaghan, E. L., Mun, J. H., Najar, F. Z., Nicholson, C., Noirot, C., O’Bleness, M., 
Paule, C. R., Poulain, J., Prion, F., Qin, B. F., Qu, C. M., Retzel, E. F., Riddle, C., Sallet, E., Samain, S., Samson, N., Sanders, I., Saurat, O., Scarpelli, C., Schiex, T., Segurens, B., Severin, A. J., Sherrier, D. J., Shi, R. H., Sims, S., Singer, S. R., Sinharoy, S., Sterck, L., Viollet, A., Wang, B. B., Wang, K. Q., Wang, M. Y., Wang, X. H., Warfsmann, J., Weissenbach, J., White, D. D., White, J. D., Wiley, G. B., Wincker, P., Xing, Y. B., Yang, L. M., Yao, Z. Y., Ying, F., Zhai, J. X., Zhou, L. P., Zuber, A., Denarie, J., Dixon, R. A., May, G. D., Schwartz, D. C., Rogers, J., Quetier, F., Town, C. D., \& Roe, B. A. (2011). The Medicago genome provides insight into the evolution of rhizobial symbioses. Nature, 480(7378), 520-524. http://dx.doi.org/10.1038/ nature10625. PMid:22089132.

Zambrowicz, A., Timmer, M., Polanowski, A., Lubec, G., \& Trziszka, T. (2013). Manufacturing of peptides exhibiting biological activity. Amino Acids, 44(2), 315-320. http://dx.doi.org/10.1007/s00726012-1379-7. PMid:22914979.

Zhang, C., Wohlhueter, R., \& Zhang, H. (2016). Genetically modified foods: a critical review of their promise and problems. Food Science and Human Wellness, 5(3), 116-123. http://dx.doi.org/10.1016/j. fshw.2016.04.002.

Zhang, X. C., Wu, X. L., Findley, S., Wan, J. R., Libault, M., Nguyen, H. T., Cannon, S. B., \& Stacey, G. (2007). Molecular evolution of lysin motif-type receptor-like kinases in plants. Plant Physiology, 144(2), 623-636. http://dx.doi.org/10.1104/pp.107.097097. PMid:17449649.

Zheng, F. Y., Wu, H. Y., Zhang, R. Z., Li, S. M., He, W. M., Wong, F. L., Li, G. Y., Zhao, S. C., \& Lam, H. M. (2016). Molecular phylogeny and dynamic evolution of disease resistance genes in the legume family. BMC Genomics, 17(1), 402. http://dx.doi.org/10.1186/s12864-0162736-9. PMid:27229309.

Zimmet, P., Alberti, K. G., \& Shaw, J. (2001). Global and societal implications of the diabetes epidemic. Nature, 414(6865), 782-787. http://dx.doi.org/10.1038/414782a. PMid:11742409.

Zou, K., Zhao, Y. Y., \& Zhang, R. Y. (2006). A cytotoxic saponin from Albizia julibrissin. Chemical \& Pharmaceutical Bulletin, 54(8), 1211-1212. http://dx.doi.org/10.1248/cpb.54.1211. PMid:16880673. 